\title{
Students Mathematic Problem Solving Process in Two Variable Linear Equation Systems from Cognitive Field Dependent Style
}

\author{
Nuraida \\ Mathematics Education, IKIP Siliwangi, asrafil.raska@gmail.com \\ Usman Aripin* \\ Mathematics Education, IKIP Siliwangi, usmanaripin@gmail.com
}

Jerito Pereira

Mathematics and Statistics, Guangxi Normal University China, pererlra@stu.gxnu.edu.cn

\begin{abstract}
This study aims to describe the process of solving mathematical problems in the subjects of a two-variable linear equation system in terms of field-dependent cognitive style. The type of research used is descriptive qualitative research. The research subjects were 15 grade VIII students in one of the public junior high schools in Cimahi City. In this study, the instrument used was a problem-solving test consisting of 2 questions on the material of a two-variable linear equation system and interviews for 3 students with field dependent cognitive style. The results showed that the steps of solving mathematical problems of students with cognitive style field dependent were categorized as good at the stage of understanding the problem and re-examining, categorized enough at the stage of planning completion, and categorized less at the stage of implementing the completion plan. This means, if field dependent students can understand the problem or problem, it will affect the next step.
\end{abstract}

Keywords: Mathematical Problem Solving Skill, Two-Variable Linear Equation System, Field Dependent Cognitive Style

\section{ABSTRAK}

Penelitian ini bertujuan untuk mendeskripsikan proses pemecahan masalah matematis pada mata pelajaran sistem persamaan linear dua variabel ditinjau dari gaya kognitif field dependent. Jenis penelitian yang digunakan merupakan penelitian deskriptif kualitatif. Subjek penelitiannya adalah 15 orang siswa kelas VIII di salah satu SMP Negeri di Kota Cimahi. Pada penelitian ini, instrumen yang digunakan adalah tes pemecahan masalah yang terdiri dari 2 soal pada materi sistem persamaan linear dua variabel dan wawancara untuk 3 siswa dengan gaya kognitif field dependent. Hasil penelitian menunjukan bahwa langkahlangkah pemecahan masalah matematis siswa bergaya kognitif field dependent berkategori baik pada tahap memahami masalah dan memeriksa kembali, berkategori cukup pada tahap merencanakan penyelesaian, serta berkategori kurang pada tahap melaksanakan rencana penyelesaian. Hal ini berarti, jika siswa field dependent dapat memahami masalah atau soal, maka akan berpengaruh pada langkah berikutnya.

Kata Kunci: Kemampuan Pemecahan Masalah Matematis, Sistem Persamaan Linear Dua Variabel, Gaya Kognitif Field Dependent

\section{INTRODUCTION}

Etymologically, mathematics comes from the Ancient Greek máthēma which means knowledge, knowledge, and learning(Jha et al., 2016; Machaba \& Dhlamini, 2021). Mathematics is one of the sciences that plays an important role(Pereira, J.; Wijaya, T.T.; Zhou, 2020). In addition to 
practicing arithmetic and logical thinking skills, the benefits of mathematics are none other than to simplify and help solve problems in everyday life. The purpose of learning mathematics is to develop problem-solving skills.

Solving skill cannot be separated from mathematics learning (Hasbullah \& Wibawa, 2021; Ibrahim et al., 2021; Nursha, G., Mirza, A., 2017; Widodo et al., 2021) . Polya (1973) suggests that problem-solving is an attempt to find a way out of a goal that is not so easily achievable. In other words, problem-solving is a series of activities in determining the solution to a problem. Polya (1973) also suggested that the solution to the problem-solving problem contains four stages of completion, namely: (1) Understanding The Problem; (2) Devising a Plan (making a problem-solving plan); (3) Carrying Out The Plan (implementing the problem-solving plans); and (4) Looking Back (looking back at the completeness of the problem solving) (Chadli et al., 2019; Gravemeijer et al., 2017; Turyanto et al., 2019).

Problem-solving skills are very important for students because (1) problem solving is a general goal of teaching mathematics, (2) mathematical problem solving includes methods, procedures, and strategies which are the core and main processes in the mathematics curriculum, even as the heart of it. mathematics, and (3) problem solving is a basic skill of mathematics. So it cannot be denied that problem-solving skills are very important both in the learning process and in everyday life. Because problem-solving is a student's first step in developing mathematical skills (Asmar \& Hafiz, 2020; Widodo et al., 2018).

In learning activities, of course, students will not be separated from solving mathematical problems that are focused on efforts to train students' mindsets in using their thinking potential (Alifah \& Aripin, 2018). Polya (1973) suggests that problem-solving is an attempt to find a way out of a goal that is not so easily achievable. In other words, problem-solving is a series of activities in determining the solution to a problem. Polya (1973) also explained that the solution to problem-solving contains four stages of completion, namely: (1) Understanding the Problem; (2) Devising a Plan; (3) Carrying Out the Plan; and (4) Looking Back (looking back at the completeness of the problem solving).

In the 2013 curriculum, problem-solving is one of the goals in the learning process. Problemsolving in mathematics needs to be learned by students so that they can combine elements of knowledge, techniques, rules, skills, and concepts that have been previously learned to obtain new solutions (Marwazi, Masrukan, \& Putra, 2020). Solving mathematical problems becomes meaningful and important to develop students' abilities in understanding mathematical concepts and solving problems (Utomo, Juniati, \& Siswono, 2017).

However, from several research results, it was found that the problem-solving skill of high school students was still relatively low, this result was revealed by Purnamasari (2015) showed that students who had problem-solving skills at high qualifications were only $11.77 \%$ and students who had low problem-solving abilities and very low as much as $52.94 \%$. Students have difficulty solving problems caused by several things, including students who do not understand the problem given (Wulan \& Anggraeni, 2020).

Nahdataeni \& Linawati (2015) reveal that the questions that are called problems are questions that cannot be done with a routine process and provide challenges in doing so. For example, when 
solving a story problem of non-routine form, the problem is not immediately solved by using a formula that has been taught from school but requires further thought in solving it. Indriyani (2018) also suggests that one form of a question that can hone problem-solving skills is story questions related to everyday life.

On the other hand, there are still many students who have difficulty in solving non-routine story questions. Students difficulties in solving problem-solving problems can be seen from research conducted by Lestari (2010) explaining that one of the errors in solving math story problems consists of conceptual errors and lack of practice in math problems. In addition, students cannot change the question sentence in the mathematical model, so students are confused or wrong when substituting the formula. Widodo (2013) also suggests that students mistakes when making problem-solving plans are that students do not know the adequacy and necessity of the requirements of a problem and do not use all the information that has been collected from the problem.

Vendiagrys \& Junaedi (2015) suggested that in solving mathematical problems, students have different abilities. The choice of solutions in solving different mathematical problems can be caused by differences in cognitive styles. Cognitive style is the way a person processes, stores or uses the information to respond to a task or various types of environmental situations (Ngilawajan, 2013). It is referred to as a style and not as an skill because it refers to how a person processes information and solves problems and does not refer to how the process of solving it is best.

Cognitive styles are divided into field dependent (FD), field independent (FI), reflective and impulsive (Azhil, Ernawati, \& Lutfianto, 2017) but in this study using a field dependent cognitive style (FD). FD cognitive style is a characteristic of someone who has a tendency to depend on the environment and is also easily influenced by the environment. In carrying out tasks or solving problems, individuals with FD style will work better if given extra instructions or guidance. However, students with FD style tend to receive or process information in general (Rahaju, 2014; Kafiar, 2015).

Table 1. Indicators of the Problem Solving Process in terms of Field Dependent Cognitive Style

\begin{tabular}{|c|c|c|c|}
\hline $\begin{array}{l}\text { Understanding the } \\
\text { Problem }\end{array}$ & Devising a Plan & Carrying Out The Plan & Looking Back \\
\hline \multirow[t]{2}{*}{$\begin{array}{l}\text { Can write down what } \\
\text { is known and ask } \\
\text { about the problem, } \\
\text { able to identify and } \\
\text { explain the information } \\
\text { obtained in their } \\
\text { language but not yet } \\
\text { clear }\end{array}$} & $\begin{array}{l}\text { Lack of or not being } \\
\text { able to find a } \\
\text { connection between } \\
\text { the facts in the } \\
\text { problem and the } \\
\text { concepts they have }\end{array}$ & $\begin{array}{l}\text { Unable to realize the } \\
\text { ideas they have in the } \\
\text { form of problem- } \\
\text { solving steps under } \\
\text { the concepts they } \\
\text { have }\end{array}$ & \multirow[t]{2}{*}{$\begin{array}{l}\text { Unable to re- } \\
\text { examine the results } \\
\text { of his work so that if } \\
\text { an error occurs the } \\
\text { subject is unable to } \\
\text { find the correct } \\
\text { answer or solution }\end{array}$} \\
\hline & $\begin{array}{l}\text { Students are } \\
\text { confused in solving } \\
\text { problems solving } \\
\text { because they are used } \\
\text { to being guided by } \\
\text { teachers and friends }\end{array}$ & $\begin{array}{l}\text { Unable to solve } \\
\text { problems with the } \\
\text { concept you have }\end{array}$ & \\
\hline
\end{tabular}

(Source: Mawardi, et al., 2020)

Based on the description above, in contrast to the research conducted by Selan \& Yunianta (2017), the focus in this study is to describe the process of mathematical problem-solving abilities 
based on the cognitive style of FD on the material of a two-variable linear equation system. The objectives to be achieved in this research are to find out and explain student profiles in the problemsolving process based on Polya's problem-solving steps. So that the FD style is suitable for use in this study which involves the problem-solving process of each research subject in accordance with the problems often faced by students when encountered in the field, especially in the material of a two-variable linear equation system that is closely related to everyday life. So this is the reason for the authors to choose the FD cognitive style based on Polya's measures to be the focus of this research.

\section{METHOD}

This research is qualitative descriptive research. Qualitative descriptive research is a method used to describe and describe existing phenomena, both natural and human-engineered, which pay more attention to the characteristics, quality, and interrelationships between activities(Martin \& McKneally, 1998; Mirhosseini, 2017) \& Sukmadinata, 2017). According to Herutomo (2014) qualitative descriptive research is research that aims to understand the phenomena experienced by research subjects related to behavior, perceptions, actions, and others, holistically and by means of descriptions of words and language, in a special context that scientific and by utilizing various scientific methods. The phenomenon described in this study is the student's problem-solving process in terms of cognitive style and analyzed using the Polya step, namely at the stage of understanding mathematical problems, planning the stages of problem-solving, implementing the solution plans that have been prepared, and re-examining the answers.

The process of selecting research subjects begins with giving a cognitive style test to class VIII students as many as 15 students using the Group Embedded Figure Test (GEFT) instrument with a score range of 0-18 developed by Witkin et al (1975) which consists of 25 items in the form of pictures that divided into 3 parts. With the criteria that students can answer correctly $0-9$ are classified as FD (Basir, 2015; Lusiana, 2017). There were three students with the lowest GEFT test scores in a row, namely student 1 with a score of 8 , student 2 with a score of 6 , and student 3 with a score of 5.

Then a problem-solving skill test was conducted. The instrument used in this research is a problem-solving skill test compiled by the author in the form of a description of 2 questions. A problem-solving problem contains a situation that can encourage students to solve it but does not directly know-how. This is in accordance with the opinion of Kesan (2010) which states that questions that are included in the problem-solving category are not easy to find a solution to because it requires a process of applying a mathematical mindset and knowledge previously possessed or acquired to new or unusual situations. Guidelines for scoring students' mathematical problem-solving tests are presented in Table 2.

Table 2. Scoring Guidelines for Mathematical Problem Solving Tests

\begin{tabular}{llcl}
$\begin{array}{c}\text { Question } \\
\text { Number }\end{array}$ & Problem Solving Steps & Score & Student Response to Problems \\
\hline $1,2,3,4$ & Step 1. Understanding the Problem & 0 & No element identification \\
\hline 4 & Students Mathematic Problem Solving Process in Two Variable Linear Equation Systems \\
from Cognitive Field Dependent Style
\end{tabular}




\begin{tabular}{|c|c|c|c|}
\hline $\begin{array}{l}\text { Question } \\
\text { Number }\end{array}$ & Problem Solving Steps & Score & Student Response to Problems \\
\hline \multirow{8}{*}{$1,2,3,4$} & \multirow{8}{*}{ Step 2. Devising a Plan } & 1 & $\begin{array}{l}\text { Element identification exists but } \\
\text { is wrong }\end{array}$ \\
\hline & & 2 & $\begin{array}{l}\text { Element identification is correct } \\
\text { but incomplete }\end{array}$ \\
\hline & & 3 & $\begin{array}{l}\text { Complete and correct element } \\
\text { identification }\end{array}$ \\
\hline & & 0 & $\begin{array}{l}\text { There is no mathematical model } \\
\text { and problem-solving planning }\end{array}$ \\
\hline & & 2 & $\begin{array}{l}\text { Mathematical models and } \\
\text { problem-solving plans exist but } \\
\text { are wrong }\end{array}$ \\
\hline & & 4 & $\begin{array}{l}\text { Mathematical models and } \\
\text { problem-solving plans are } \\
\text { incomplete }\end{array}$ \\
\hline & & 7 & $\begin{array}{l}\text { Mathematical models and } \\
\text { planning problem-solving is } \\
\text { correct however less complete }\end{array}$ \\
\hline & & 10 & $\begin{array}{l}\text { Complete and correct } \\
\text { mathematical model and problem- } \\
\text { solving planning }\end{array}$ \\
\hline \multirow[t]{5}{*}{$1,2,3,4$} & \multirow[t]{5}{*}{ Step 3. Carrying Out The Plan } & 0 & $\begin{array}{l}\text { There is no appropriate } \\
\text { calculation problem-solving } \\
\text { planning }\end{array}$ \\
\hline & & 2 & $\begin{array}{l}\text { Calculation according to plan } \\
\text { there is a solution to the problem } \\
\text { but it's wrong }\end{array}$ \\
\hline & & 6 & $\begin{array}{l}\text { Calculation according to plan } \\
\text { incomplete problem-solving }\end{array}$ \\
\hline & & 9 & $\begin{array}{l}\text { Calculation according to plan } \\
\text { problem-solving is correct but } \\
\text { incomplete }\end{array}$ \\
\hline & & 15 & $\begin{array}{l}\text { Calculation according to plan } \\
\text { complete and correct problem- } \\
\text { solving }\end{array}$ \\
\hline \multirow[t]{3}{*}{$1,2,3,4$} & \multirow[t]{3}{*}{ Step 4. Looking Back } & 0 & No conclusion results calculation \\
\hline & & 1 & \\
\hline & & 2 & $\begin{array}{l}\text { The conclusion of the calculation } \\
\text { results are complete and correct }\end{array}$ \\
\hline
\end{tabular}

(Source: Sari, 2016)

\section{RESULT AND DISCUSSION}

The data used is the result of student work on a problem-solving skill test that has a Field Dependent (FD) cognitive style.

\section{$1^{\text {st }}$ Process of Students Problem Solving on the System of Linear Equations with Two Variables}

At the stage of understanding the problem, based on the results of student answers in Figure 1 , student 1 did not rewrite the things that were known and asked in the questions and did not completely state the things that were known and asked in the questions. However, when the interview was conducted, it turned out that student 1 understood the problems contained in the questions. 


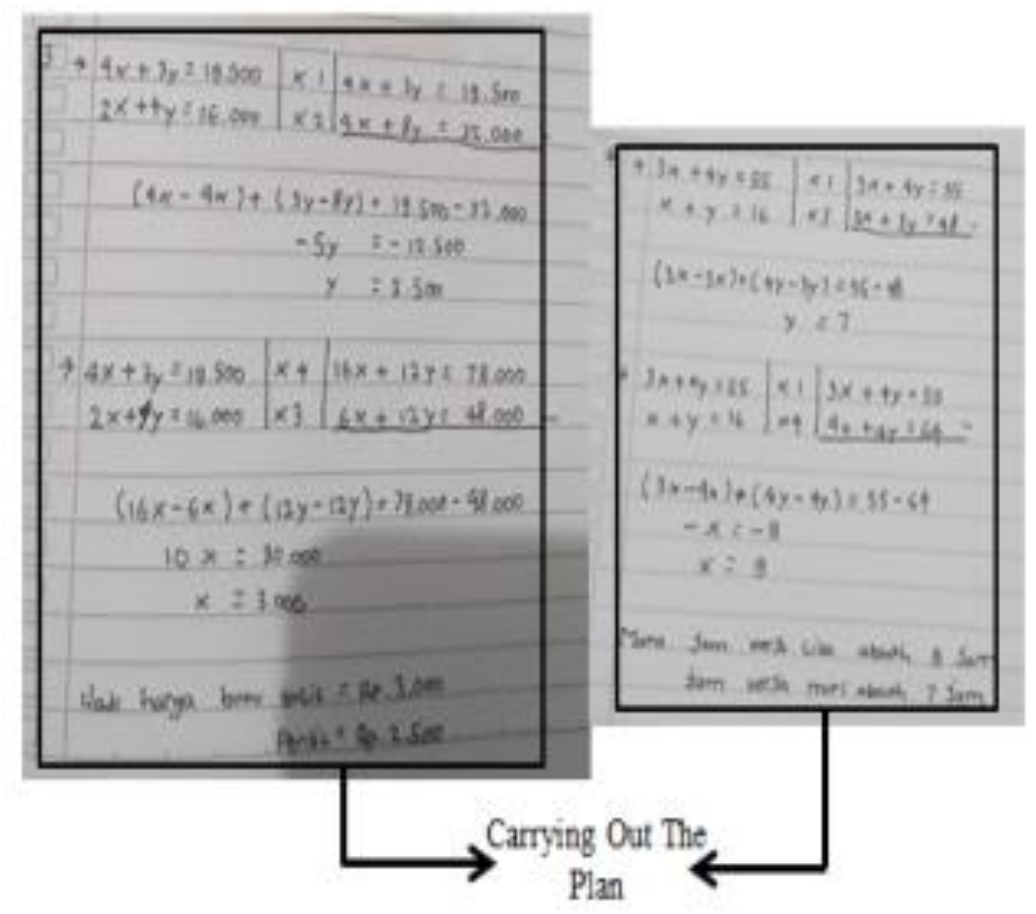

Figure 1. Answers to Questions by Student 1

The stage of understanding the problem can be seen in the results of the interview as follows:

$P$ : What was the first thing you did after receiving the question sheet?

S1: Read the questions carefully and then start working on them.

$P$ : Do you understand the information that is it on the question sheet?

S1: Yes I understand.

$P$ : Why don't you write down what you know and what is asked in the question in your answer?

S1: Because I have understood the matter, ma'am. So write down the answer directly.

At the stage of planning a problem-solving solution, based on the results of student answers in Figure 1, student 1 assumes the things contained in the problem and uses the concept of a twovariable system of linear equations to solve the problem. This can be seen in student 1 's answer, for example by using the variables $x$ and $y$.

At the stage of implementing the problem-solving plan, based on the results of student answers in Figure 1, student 1 is able to solve the problem according to the plan that has been made and provide conclusions and appropriate answers to solve the problem.

At the re-examination stage, based on the results of student answers in Figure 1, it can be shown that student 1 did a re-examination. The stage of re-examination can be seen from student 1 's answer which concludes in the sentence: "So the price of a notebook is Rp. 3,000 and the price of a pencil are Rp. 2,500" and the sentence "So Lisa's working hours are 9 hours and Muri's 7 hours". By writing conclusions, students have checked what was asked in the question with the results obtained. 


\section{$2^{\text {nd }}$ Process of Students Problem Solving on the System of Linear Equations with Two Variables}

At the stage of understanding the problem, based on the results of student answers in Figure 2 , student 2 rewrote the things that were known and asked in the question but did not completely state the things that were known and asked in the question. FD subjects replaced what was known and asked into mathematical sentences, but not all of them were successfully translated, some were still in the form of ordinary verbal sentences (Marwazi, Masrukan, \& Putra, 2019).

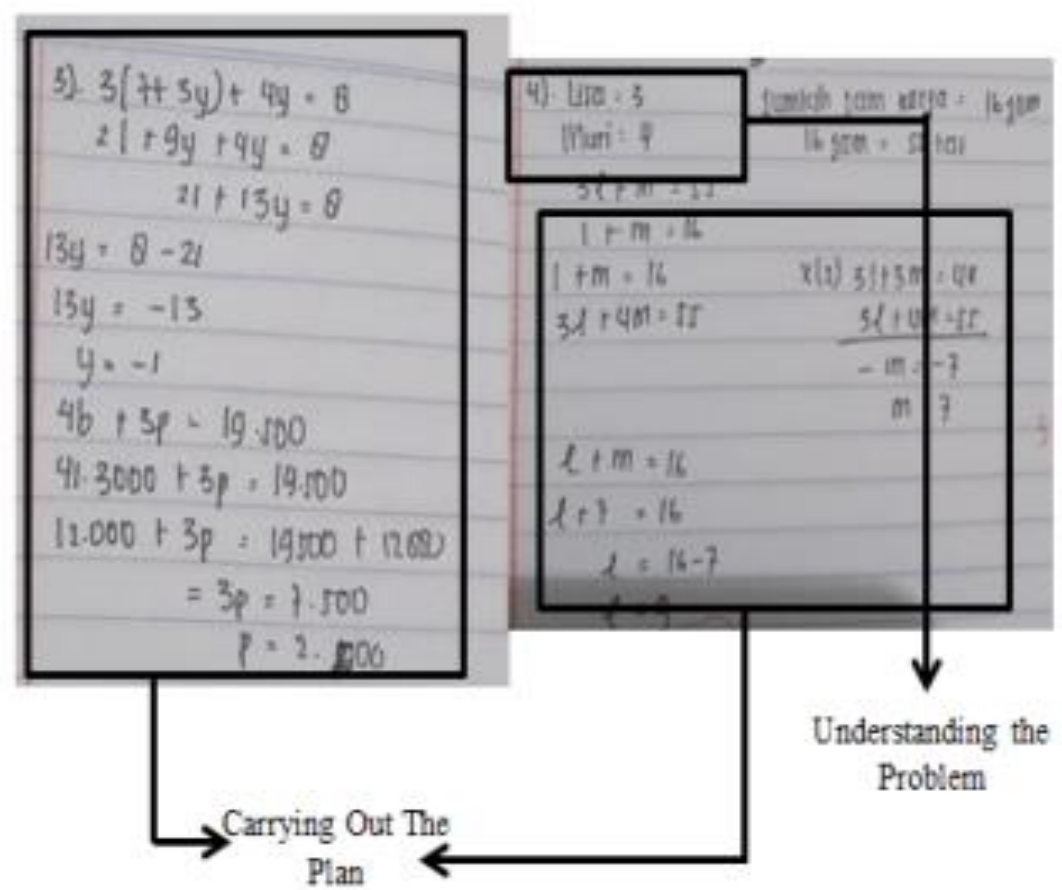

Figure 2. Answers to Questions by Student 2

The stage of understanding the problem can be seen from interviews with 2 FD students.

$P$ : Do you understand the information in the questions?

S2: Yes. I wrote down again what was known in the question but it was incomplete.

$P$ : Try to explain what you understand in this matter!

S2: The command of the question is to determine the price of a pencil and a notebook. And to determine Lisa and Muri's working hours.

At the stage of planning a problem-solving solution, based on the results of students' answers in Figure 2, student 2 assumes the things contained in the problem using the variables $x$ and $y$, and uses the concept of a system of linear equations with two variables to solve the problem. The plans and actions decided to be used by FD students do not lead to the correct solution, this is because FD students receive information globally so they are less able to organize information independently and use less correct solutions (Haryanti, 2018; Hardianto, 2018). The following are excerpts from interviews with students of 2 FD subjects.

$P:$ To work on this problem, what is the first step you take?

S2: Write down what is known and make a mathematical model, ma'am.

$P:$ Why did you make a mathematical model first to work on the problem?

S2: Because to make it easier to do. 
At the stage of implementing the problem-solving plan, based on the results of student answers in Figure 2, student 2 is less able to solve the problem according to the plan that has been made and does not provide appropriate conclusions and answers.

At the re-examination stage, based on the results of student answers in Figure 2, it cannot show that student 2 has re-examined. Because student 2 could not find the mistakes made so student 2 could not correct the existing mistakes. This is in line with research (Nugraha, \& Zanthy, 2018) which shows that students' mathematical problem-solving abilities are still low, especially at the stage of re-examining the answers obtained. The following is an excerpt from the results of student interviews with 2 FD subjects.

$P$ : After you solve the problem, do you check the results again?

S2: No.

$P$ : Why don't you double check your answer?

S2: Because I was sure of my answer.

\section{$3^{\text {rd }}$ Process of Students Problem Solving on the System of Linear Equations with Two Variables}

At the stage of understanding the problem, based on the results of student answers in Figure 3 , student 3 did not rewrite the things that were known and asked in the questions and did not completely state the things that were known and asked in the questions. This is because students with FD style are not guided in doing problem-solving tests, while FD students like to seek guidance and instructions from teachers (Yasa, Sadra \& Suweken, 2013).

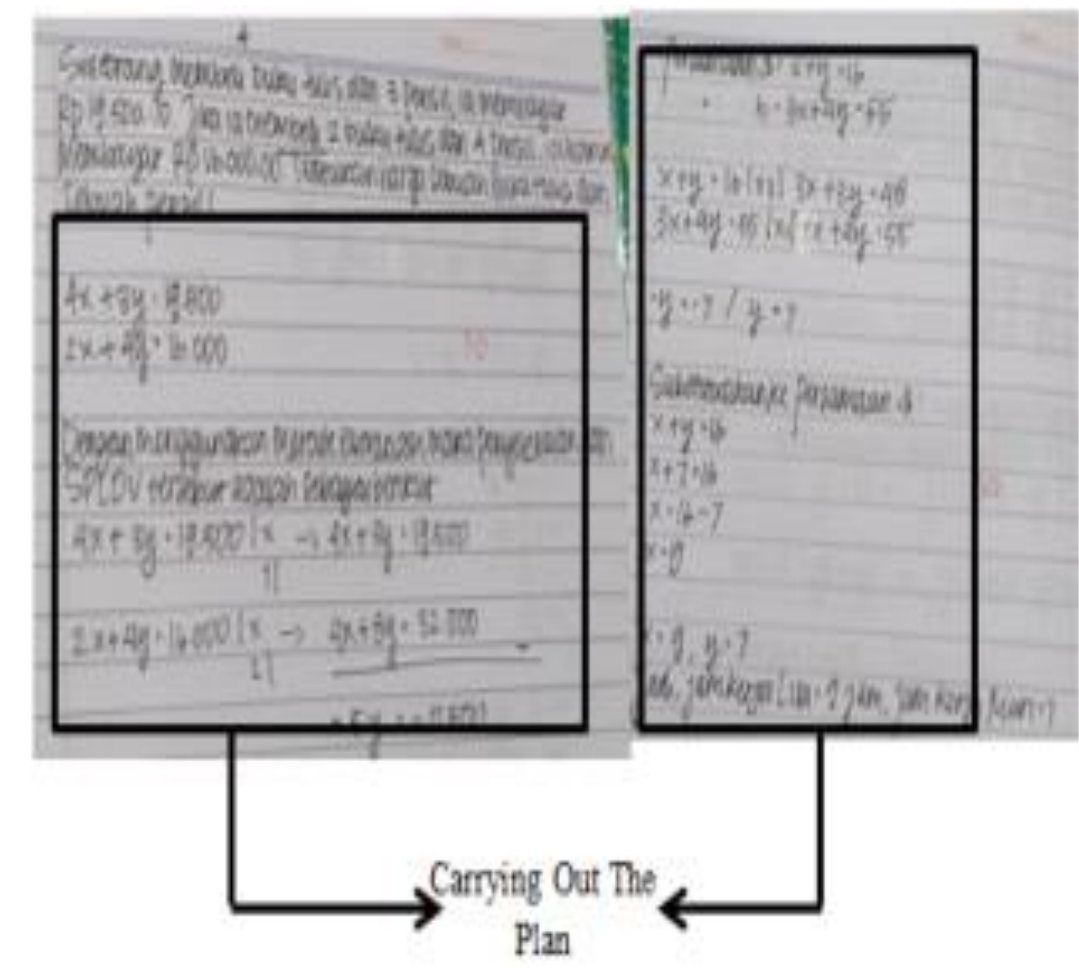

Figure 3. Answers to Questions by Student 3

At the stage of planning a problem-solving solution, based on the results of students' answers in Figure 3, student 3 assumes the things contained in the problem using $x$ and $y$ variables, and does 
not use the concept of a two-variable linear equation system to solve the problem because it takes a long time to remember the concept of the material. This is in line with the results of previous studies, FD students are not yet complete in developing strategies (Geni, Mastur \& Hidayah, 2017).

At the stage of implementing the problem solving plan, based on the results of student answers in Figure 3, student 3 is less able to solve problems according to the plan that has been made and does not provide appropriate conclusions and answers.

At the re-examination stage, based on the results of students' answers in Figure 3, it cannot show that student 3 has re-examined. This is in line with Nurhayati (2013) who said that students ignore Polya's fourth step in solving problems, namely looking back at the complete solution correctly. The re-examination stage can be seen from the results of interviews with students of 3 FD subjects.

$P$ : After you solve the problem, do you check the results again?

S3: Yes, I checked the answer again.

$P$ : How many times have you checked your answers?

S3: I checked the answer once.

$P$ : Are you sure about your answer?

S3: Yes of course.

Table 3. Profile of the Problem Solving Process Subject Student 1, Student 2, and Student 3

\begin{tabular}{|c|c|c|c|}
\hline Polya's Steps & $\begin{array}{l}\text { Student Problem } \\
\text { Solving Process } 1\end{array}$ & $\begin{array}{l}\text { Student Problem } \\
\text { Solving Process } 2\end{array}$ & $\begin{array}{l}\text { Student Problem } \\
\text { Solving Process } 3\end{array}$ \\
\hline $\begin{array}{l}\text { Understanding the } \\
\text { Problem }\end{array}$ & $\begin{array}{l}\text { Do not rewrite things } \\
\text { that are known and } \\
\text { asked in written } \\
\text { questions. During the } \\
\text { interview, student } 1 \\
\text { proved to understand } \\
\text { the problem }\end{array}$ & $\begin{array}{l}\text { Rewrite the things that } \\
\text { are known and asked } \\
\text { in the questions but do } \\
\text { not completely state } \\
\text { the things that are } \\
\text { known and asked in } \\
\text { the questions }\end{array}$ & $\begin{array}{l}\text { Do not rewrite things } \\
\text { that are known and } \\
\text { asked in the question }\end{array}$ \\
\hline Devising a Plan & $\begin{array}{l}\text { Assume the things } \\
\text { contained in the } \\
\text { problem by using } \\
\text { mathematical symbols } \\
\text { and working on the } \\
\text { problem according to } \\
\text { the concept }\end{array}$ & $\begin{array}{l}\text { Give examples of } \\
\text { things in the problem }\end{array}$ & $\begin{array}{l}\text { Suppose the things } \\
\text { contained in the } \\
\text { problem by using } \\
\text { symbols and not using } \\
\text { concepts to solve } \\
\text { problems }\end{array}$ \\
\hline $\begin{array}{l}\text { Carrying Out The } \\
\text { Plan }\end{array}$ & $\begin{array}{l}\text { Able to solve } \\
\text { problems and provide } \\
\text { appropriate } \\
\text { conclusions and } \\
\text { answers to solve } \\
\text { problems }\end{array}$ & $\begin{array}{l}\text { Less able to solve } \\
\text { problems and less } \\
\text { provide conclusions } \\
\text { and appropriate } \\
\text { answers }\end{array}$ & $\begin{array}{l}\text { Less able to solve } \\
\text { problems and less } \\
\text { provide conclusions } \\
\text { and appropriate } \\
\text { answers }\end{array}$ \\
\hline Looking Back & $\begin{array}{l}\text { Make a final } \\
\text { conclusion on the } \\
\text { answer }\end{array}$ & $\begin{array}{l}\text { Can't prove the } \\
\text { answer yet }\end{array}$ & $\begin{array}{l}\text { Check answers that } \\
\text { are proven at the } \\
\text { interview }\end{array}$ \\
\hline
\end{tabular}

From the results of the above analysis, it can be concluded that students with field-dependent cognitive styles have good mathematical problem-solving abilities because they can only achieve several problem-solving steps. At the stage of understanding the problem and re-examining, students with field-dependent cognitive style can be said to be categorized as good enough because they can write down the known data on the problem even though they are still lacking in mentioning the known data. From the results of the interviews, it can be seen that the FD students did a re-examination. At 
the stage of planning for completion, it can be said that it is categorized as sufficient because FD students wrote one settlement strategy but there were several steps that were not written. Meanwhile, at the stage of implementing the completion plan, the category is less because FD students can write the completion steps sequentially but it is still not correct because there are concepts used that are not precise and there are errors in calculations.

Thus this is in accordance with research conducted by Haloho (2016) and Syarifuddin (2020) which state that the problem-solving abilities of students with FD cognitive style are categorized as good at the stage of understanding the problem and re-examining, categorized enough at the stage of planning a solution, and categorized as less at the stage of implementing the completion plan. In this study it can be said that if FD students can understand the problem well, then this will affect the next steps.

\section{CONCLUSION}

Based on the results of the analysis and discussion, it can be concluded that there is a tendency for students to solve problems, students with FD cognitive style are categorized as good at the stage of understanding the problem and re-examining, categorized enough at the stage of planning completion, and categorized less at the stage of implementing the completion plan because students Field dependent cognitive style requires encouragement or more detailed instructions to solve a problem.

This research is expected to provide input for teachers as facilitators who handle students directly to pay attention to students' mathematical problem-solving abilities so that students are accustomed to solving problem-solving problems.

\section{ACKNOWLEDGEMENT}

The researcher was very aware when the compilers of this article could not complete without the cooperation of various parties. Therefore, on this occasion, the researcher were very grateful to the school, teachers and students who have participated and helped. For all the support from various related parties, we say thank you.

\section{REFERENCES}

Alifah, N., \& Aripin, U. (2018). Proses Berpikir Siswa Smp Dalam Memecahkan Masalah Matematik Ditinjau Dari Gaya Kognitif Field Dependent Dan Field Independent. JPMI (Jurnal Pembelajaran Matematika Inovatif), 1(4), 505. https://doi.org/10.22460/jpmi.v1i4.p505-512

Asmar, A., \& Hafiz, M. (2020). Improvement students' problem solving ability through problem centered learning (Pcl). International Journal of Scientific and Technology Research, 9(2), 6214-6217.

Azhil, I. M., Ernawati, A., \& Lutfianto, M. (2017). Profil Pemecahan Masalah Matematika Siswa Ditinjau dari Gaya Kognitif Reflektif dan Impulsif. JURNAL REVIEW PEMBELAJARAN MATEMATIKA, 2(1), 60-68.

Basir, M. A. (2015). Kemampuan Penalaran Siswa dalam Pemecahan Masalah Matematis Ditinjau dari Gaya Kognitif. Jurnal Pendidikan Matematika FKIP Unissula, 3(1), 106-114.

Chadli, A., Tranvouez, E., \& Bendella, F. (2019). Learning Word Problem Solving Process in Primary School Students: An Attempt to Combine Serious Game and Polya's Problem Solving Model. Springer Singapore. https://doi.org/10.1007/978-981-32-9335-9_8

Geni, P. R. L., Mastur, Z., \& Hidayah, I. (2017). Kemampuan Pemecahan Masalah Siswa pada 
Pembelajaran Problem Based Learning Bernuansa Etnomatematika Ditinjau dari Gaya Kognitif. Unnes Journal of Mathematics Education Research, 6(1), 11-17.

Gravemeijer, K., Stephan, M., Julie, C., Lin, F. L., \& Ohtani, M. (2017). What Mathematics Education May Prepare Students for the Society of the Future? International Journal of Science and Mathematics Education, 15, 105-123. https://doi.org/10.1007/s10763-017-9814-6

Haloho, S. H. (2016). Analisis Kemampuan Pemecahan Masalah Ditinjau Dari Gaya Kognitif Siswa Pada Model Pembelajaran Missouri Mathematics Project. Universitas Negeri Semarang.

Hardianto, H. (2018). Deskripsi Proses Berpikir Siswa dalam Menyelesaikan Soal Pisa Berdasarkan Gaya Kognitif. Prosiding, 3(1).

Haryanti, C. F., \& M. (2018). Profil Penalaran Matematika Siswa SMP dalam Memecahkan Masalah Open Ended Ditinjau dari Gaya Kognitif Field Dependent dan Field Independent. MATHEdunesa, 7(2).

Hasbullah, H., \& Wibawa, B. (2021). Analysis of Mathematics Students Ability in Learning Metacognitive Strategy Type Ideal (Identify, Define, Explore, Act, Look). International Electronic Journal of Mathematics Education, 12(3), 859-872. https://doi.org/10.29333/iejme/653

Herutomo, S. (2014). Analisis Kesalahan Dan Miskonsepsi Siswa Kelas Viii Pada Materi Aljabar. Jurnal Ilmu Pendidikan Dan Pengajaran, I(2).

Ibrahim, I., Sujadi, I., Maarif, S., \& Widodo, S. A. (2021). Increasing Mathematical Critical Thinking Skills Using Advocacy Learning with Mathematical Problem Solving. Jurnal Didaktik Matematika, 8(1), 1-14.

Indriyani, F. (2018). Analisis Kemampuan Pemecahan Masalah dengan Tahapan IDEAL Problem Solving. Pythagoras, 7(2), 56-67.

Istiqomah, Nurul dan Rahaju, E. B. (2014). Proses Berpikir Siswa Sekolah Menengah Pertama (SMP) dalam Menyelesaikan Soal Cerita Matematika Berdasarkan Gaya Kognitif pada Materi Bangun Ruang Sisi Lengkung. Jurnal IImiah Pendidikan Matematika, 3(2).

Jha, P. K., Panthi, D., \& Jha, K. (2016). Fixed point, kutasth vindu and Vedanta philosophy. 2(6), 167-169.

Kafiar. (2015). Proses Berpikir Siswa SMA Dalam Memecahkan Masalah Matematika Pada Materi SPLTV Ditinjau Dari Gaya Kognitif Field Dependent dan Field Independent. Jurnal IImiah Matematika Dan Pembelajarannya.

Kesan, C., Kaya, D., dan Guvercin, S. (2010). The Effect of Problem Posing Approach to the Gifted Student's Mathematical Abilities. International Online Journal of Educational Sciences, 2(3), 677-687.

Lestari, Nur I., Anton Noornia, dan Wardani RahayuLestari, Nur I., Anton Noornia, dan W. R. (2010). Analisis Kemampuan Siswa SD dalam Menerjemahkan Soal Cerita ke dalam Model Matematika dan Penyelesaiannya. Jurnal Matematika, Aplikasi Dan Pembelajarannya, 9(1), 22-34.

Lusiana, R. (2017). Analisis kesalahan Mahasiswa dalam memecahkan masalah pada materi himpunan ditinjau dari gaya kognitif. Jurnal Penelitian Dan Pembelajaran Matematika, 10(1).

Machaba, F., \& Dhlamini, J. (2021). Ethnomathematics as a Fundamental Teaching Approach. 5976.

Martin, D. K., \& McKneally, M. F. (1998). Qualitative Research. In Surgical research (pp. 235-241). Springer.

Marwazi, M., Masrukan, M., \& Putra, N. M. D. (2019). Analysis of Problem Solving Ability Based on Field Dependent Cognitive Style in Discovery Learning Models. Journal of Primary Education, 127-134.

Mawardi, A. V., Yanti, A. W., \& A., \& Y. (2020). Analisis Proses Berpikir Siswa dalam Menyelesaikan Soal HOTS Ditinjau dari Gaya Kognitif. Jurnal Review Pembelajaran Matematika, 5(1), 40-52.

Mirhosseini, S. A. (2017). Introduction: Qualitative Research in Language and Literacy Education. Educational Linguistics, 29, 1-13. https://doi.org/10.1007/978-3-319-49140-0_1

Nahdataeni, S. S., \& L. (2015). Proses Berpikir Siswa dalam Memecahkan Masalah Sistem Persamaan Linier Dua Variabel Ditinjau dari Gaya Belajar di Kelas X SMA Negeri 2 Palu. AKSIOMA Jurnal Pendidikan Matematika, 4(2).

Ngilawajan, D. A. (2013). Proses Berpikir Siswa SMA da1am Memecahkan Masa1ah Matematika Materi Turunan Ditinjau Dari Gaya Kognitif Fie1d Independent dan Fie1d Dependent. PEDAGOGIA: Jurna1 Pendidikan, 2(1), 71-83.

Nugraha, A., \& Zanthy, L. S. (2018). Analisis Kemampuan Pemecahan Masalah Siswa Sma Pada Materi Sistem Persamaan Linear. Journal on Education, 1(2), 179-187.

Nurhayati. (2013). Penerapan Langkah-Langkah Polya untuk Meningkatkan Hasil Belajar Siswa dalam Menyelesaikan Soal Cerita Himpunan di Kelas VII SMP Nasional Wani. Jurnal Elektronik 
Pendidikan Matematika Tadulako, 1(1), 115-128.

Nursha, G., Mirza, A., \& B. (2017). Proses Berpikir Siswa da1am Menye1esaikan Soa1 Cerita Ditinjau dari Gaya Kognitif Materi Kubus dan Ba1ok. Jurnal Pendidikan Dan Pembelajaran Khatulistiwa, 6(7), 1-7.

Pereira, J.; Wijaya, T.T.; Zhou, Y. . P. (2020). Learning points, lines, and plane geometry with Hawgent dynamic mathematics software. Journal of Physics: Conference Series. https://doi.org/10.1088/1742-6596/1882/1/012057

Polya, G. (1973). How To So1ve It : A New Aspect of Mathematica1 Method (2nd ed.). Princeton, New Jersey: Princeton University Press.

Purnamasari, P. D. (2015). Analisis kemampuan pemecahan masalah matematika siswa kelas XI SMK Muhammadiyah I Patuk pada pokok bahasan peluang. Jurnal Pendidikan Matematika Dan Sains, 1(1), 1-7.

Sari, D. P. (2016). Analisis Kemampuan Pemecahan Masalah Matematika Siswa Ditinjau Dari Kemampuan Berpikir Kreatif Matematis Siswa.

Selan, D., \& Yunianta, T. N. H. (2017). Analisis Kemampuan Pemecahan Masalah Peserta Didik Kelas 8 Berdasarkan Tahapan Ideal Untuk Materi Spldv Bentuk Tidak Rutin. Satya Widya, 2012, 133-143.

Sukmadinata. (2017). Metode Penelitian Pendidikan. PT Remaja Rosdakarya.

Syarifuddin, A. (2020). Kemampuan Pemecahan Masalah Ditinjau Dari Gaya Kognitif Dengan Model Problem Based Learning. Jurnal Ilmiah Pendidikan, 8(1), 1-9. https://doi.org/10.33659/cip.v8i1.145

Turyanto, T., Agustito, D., \& Widodo, S. A. (2019). Think Pair Share With Comic For Mathematical Problem Solving Skills. Formatif: Jurnal IImiah Pendidikan MIPA, 9(3).

Utomo, E. S., Juniati, D., \& Siswono, T. Y. E. (2017). Mathematical Visualization Process of Junior High School Students in Solving A Contextual Problem Based on Cognitive Style. AIP Conference Proceedings, 1868(050011).

Vendiagrys, L., \& Junaedi, L. (2015). Analisis Kemampuan Pemecahan Masalah Matematika Soal Setipe Siswa da1am Menyelesaikan Masa1ah Matematika Berdasarkan Teori Pemrosesan Informasi. Suska Journa1 of Mathematics Education, 4(2), 125-141.

Widodo, Sri A. (2013). Analisis Kesalahan dalam Pemecahan Masalah Divergen Tipe Membuktikan pada Mahasiswa Matematika. Jurnal Pendidikan Dan Pengajaran, 2, 106-113.

Widodo, Sri Adi, Darhim, \& Ikhwanudin, T. (2018). Improving mathematical problem solving skills through visual media Improving mathematical problem solving skills through visual media. Journal of Physics: Conf. Series, 948(1), 1-6. https://doi.org/10.1088/1742-6596/948/1/012004

Widodo, Sri Adi, Ibrahim, I., Hidayat, W., Maarif, S., \& Sulistyowati, F. (2021). Development of Mathematical Problem Solving Tests on Geometry for Junior High School Students. Jurnal Elemen, 7(1), 221-231. https://doi.org/10.29408/jel.v7i1.2973

Witkin, H. A., Moore, C. A., Goodenough, D. R., \& Cox, P. W. (1975). Field-Dependent And FieldIndependent Cognitive Styles And Their Educational Implications. ETS Research Bulletin Series, 1975(2), 1-64. https://doi.org/10.1002/j.2333-8504.1975.tb01065.x

Wulan, Eka \& Anggraeni, R. (2020). Gaya Kognitif Field-Dependent Dan Field-Independent Sebagai Jendela Profil Pemecahan Masalah Polya Dari Siswa SMP. Jurnal Focus Action of Research Mathematic, 01, 123-142.

Yasa, I. M. A., Sadra, I. W., \& Suweken, G. (2013). Pengaruh Pendidikan Matematika Realistik dan Gaya Kognitif terhadap Prestasi Belajar Matematika Siswa. Jurnal Pendidikan Dan Pembelajaran Matematika Indonesia, 2. 